\title{
T category of non-small cell lung cancer invading the fissure to the adjacent lobe
}

\author{
Ming Liu, MD, PhD, ${ }^{\text {a,b }}$ Dennis Wigle, MD, PhD, ${ }^{\mathrm{c}}$ Jason A. Wampfler, $\mathrm{PhD},{ }^{\mathrm{d}}$ Jie Dai, MD, ${ }^{\mathrm{a}, \mathrm{b}}$ \\ Shawn M. Stoddard, RN, ${ }^{\mathrm{b}}$ Zhiqiang Xue, MD, ${ }^{\mathrm{b}, \mathrm{e}}$ Francis C. Nichols, MD, PhD, ${ }^{\mathrm{c}}$ Gening Jiang, MD, ${ }^{\mathrm{a}}$ and \\ Ping Yang, $\mathrm{MD}, \mathrm{PhD}^{\mathrm{b}}$
}

\begin{abstract}
Background: Dispute arises in the tumor category of non-small cell lung cancer invading the fissure to the adjacent lobe. The purpose of this study is to determine the long-term prognosis of non-small cell lung cancer with such an invasion and to propose an appropriate $\mathrm{T}$ category.
\end{abstract}

Methods: In total, 53 cases of non-small cell lung cancer invading the fissure to the adjacent lobe (fissure group) were identified in patients who underwent pulmonary resection from 1997 to 2014. Propensity score matching was applied to balance known confounders for prognosis between each paired group, resulting in 3 matched sets (fissure vs T2a, fissure vs T2b, and fissure vs T3). The overall survival of the fissure group was compared with the survival of patients with T2a, T2b, and T3 diseases, as classified in the eighth edition of TNM classification.

Results: The 5-year survivals of the T2a, T2b, T3, and fissure groups were $64.2 \%$ (95\% confidence interval, 53.2-72.6), 54.6\% (95\% confidence interval, $44.7-$ 65.8 ), 35.8\% (95\% confidence interval, $22.8-44.2)$, and $38.6 \%$ (95\% confidence interval, 25.0-52.2), respectively. Specifically, the difference between the fissure group and T2a is statistically significant at $P=.01$; between the fissure group and T2b at $P=.02$; and between the fissure group and T3 at $P=.93$. Multivariate analyses indicate that the fissure group had a similar risk of dying as the T3 disease group (hazard ratio, 1.10; 95\% confidence interval, 0.69-1.37) and was at a significantly higher risk compared with the T2a group (hazard ratio, 2.34; 95\% confidence interval, 1.50-3.39) and T2b group (hazard ratio, $1.71 ; 95 \%$ confidence interval, 1.19-2.76).

Conclusions: On the basis of our single-institution study, we propose that non-small cell lung cancer invading the fissure to the adjacent lobe should be further investigated and the impact on patients' prognoses validated as a T3 disease. (J Thorac Cardiovasc Surg 2017;154:1777-83)

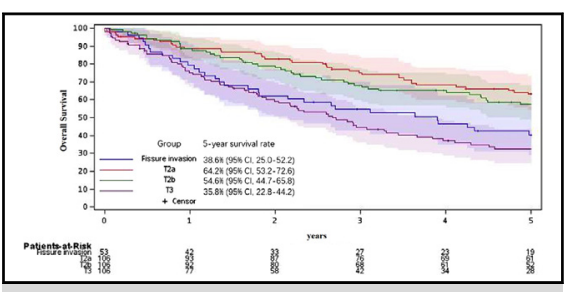

Overall survival of matched patients with fissure invasion, T2a, T2b, and T3 disease.

\section{Central Message}

NSCLC invading the fissure to the adjacent lobe has similar survival and risk of dying as T3 disease. This should be further investigated, and the impact on patients' prognoses should be validated as a $\mathrm{T} 3$ disease.

\section{Perspective}

There is no highlighted proposal for lung cancer invading the fissure to the adjacent lobe in the eighth edition of TNM classification, and it remains $\mathrm{T} 2$ disease as expressed in the Union for International Cancer Control TNM Supplement. However, this type of lung cancer involves at least 2 lobes and has a different prognosis of $\mathrm{T} 2$ disease. $\mathrm{T} 3$ disease may be the appropriate category for this type of lung cancer in the new TNM classification.

See Editorial Commentary page 1784.

\footnotetext{
From the a Department of Thoracic Surgery, Shanghai Pulmonary Hospital, Tongji University School of Medicine, Shanghai; ${ }^{b}$ Divisions of Epidemiology and ${ }^{\mathrm{d}}$ Biomedical Statistics and Informatics, Department of Health Sciences Research, and ${ }^{\mathrm{c}}$ Division of General Thoracic Surgery, Department of Surgery, Mayo Clinic College of Medicine, Rochester, Minn; and ${ }^{\mathrm{e}}$ The General Hospital of People's Liberation Army (301 Hospital), Beijing, China.

The work was supported by National Institutes of Health Grants (NIH-R01-84354) and Mayo Clinic Foundation.

Received for publication Jan 24, 2017; revisions received June 21, 2017; accepted for publication July 7, 2017.

Address for reprints: Ping Yang, MD, PhD, Division of Epidemiology, Department of Health Sciences Research, Mayo Clinic College of Medicine, 200 First St SW, Rochester, MN 55905 (E-mail: yang.ping@mayo.edu).

$0022-5223 / \$ 36.00$

Copyright (C) 2017 by The American Association for Thoracic Surgery

http://dx.doi.org/10.1016/j.jtcvs.2017.07.069
}

The TNM staging system of lung cancer is used as a guide for prognosis and is helpful when selecting proper treatment for patients with non-small cell lung cancer (NSCLC). ${ }^{1}$ Lung cancer invading the fissure to the adjacent lobe has not been taken into consideration as an official $\mathrm{T}$ descriptor in the present TNM classification. According to the seventh edition of TNM classification and the TNM supplement of

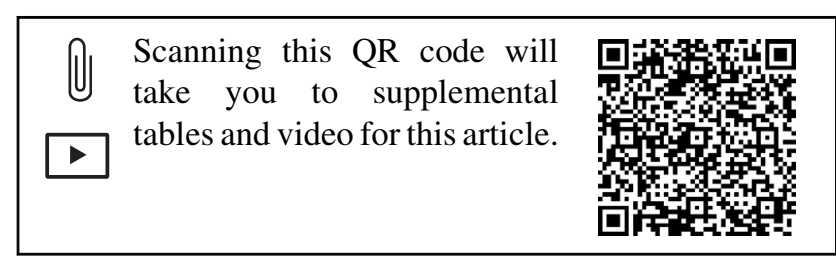




\section{Abbreviations and Acronyms \\ $\mathrm{CT}=$ computed tomography \\ NSCLC $=$ non-small cell lung cancer}

the Union for International Cancer Control, tumors invading the fissure to the adjacent lobe with a diameter of less than $7 \mathrm{~cm}$ were classified as T2.,3 However, survival dispute arises in the T category of NSCLC invading the fissure to the adjacent lobe. Ambiguity exists when classifying NSCLC with such a fissure invasion as $\mathrm{T} 2$ or $\mathrm{T} 3{ }^{4-7}$

The T category was revised in the eighth edition of TNM classification proposed by the International Association for the Study of Lung Cancer. ${ }^{8}$ T2 was reclassified as T2a $(3 \mathrm{~cm}<$ tumor $\leq 4 \mathrm{~cm})$ and T2b $(4 \mathrm{~cm}<$ tumor $\leq 5 \mathrm{~cm})$. Tumors greater than $5 \mathrm{~cm}$ and less than $7 \mathrm{~cm}$ were classified as T3; tumors greater than $7 \mathrm{~cm}$ or with diaphragm invasion were classified as T4; and tumors involving the main bronchus or with atelectasis or pneumonitis were reclassified as T2. There is no highlighted proposal of lung cancer invading the fissure to the adjacent lobe in the eighth edition of TNM classification. The lower option is used when there is uncertainty about assigning a specific category. It seems NSCLC with fissure invasion should still be classified as T2 in the new TNM classification. However, this type of NSCLC involves at least 2 lobes and has a different prognosis of $\mathrm{T} 2$ disease. The purpose of this study is to assess the survival of patients with NSCLC invading the fissure to the adjacent lobe and determine the most appropriate $\mathrm{T}$ category, as defined in the eighth edition of TNM classification.

\section{PATIENTS AND METHODS \\ Patients and Data Collection}

This retrospective study protocol was reviewed and approved by the Mayo Clinic Institutional Review Board. The detail of study protocol has been reported. ${ }^{9,10}$ In brief, from January 1997 to December 2014 at the Mayo Clinic (Rochester, Minn), all patients pathologically diagnosed and treated with primary NSCLC have been prospectively enrolled and followed for outcome research through written informed consent. The patients with NSCLC invading the fissure to the adjacent lobe (fissure group) met the following criteria: (1) primary NSCLC with tumor less than $5 \mathrm{~cm}$ in greatest dimension; (2) tumor was considered resectable preoperatively and received surgical management; and (3) peripheral NSCLC invading the fissure (visceral pleura) to the adjacent lobe. ${ }^{4}$ Medical record data included age, sex, smoking status, surgical type, histology, and pulmonary function. Mediastinal lymph node stations typically dissected were $2 \mathrm{R}, 4 \mathrm{R}, 7,8$, and 9 for right-sided procedures, and 5, 6, 7, 8, and 9 for left-sided procedures. Cases with $\mathrm{N} 2$ disease were excluded from this study. T category of all tumors was reclassified postoperatively, according to the eighth edition of TNM classification proposed by the International Association for the Study of Lung Cancer. ${ }^{11}$

Postoperative mortality included all deaths occurring within 30 days after the procedure and those caused by operative procedure during initial operative hospitalization. Follow-up data were collected through detailed medical record abstraction and self-administered questionnaires, including present health and treatment update starting within 6 months after diagnosis and annually thereafter. The vital status of each patient was verified annually through the Mayo Clinic's electronic medical notes and registration database, next-of-kin reports, death certificates, and obituary documents filed in the patients' medical records, as well as through the Mayo Clinic Tumor Registry and the Social Security Death Index website.

\section{Statistical Analysis}

The descriptive statistics for categoric variables are reported as frequencies, percentages, and continuous variables (mean \pm standard deviation). Nominal categoric variables were compared using chi-square tests; ordinal categoric variables were compared using Wilcoxon rank-sum tests. Patients whose follow-up time was less than 30 days or who died within 30 days after surgery were excluded from the survival analysis. The time of death due to any cause or the time of last follow-up was the ending point. Cumulative overall survival was estimated with a Kaplan-Meier model. A Cox proportional hazards model was estimated for both univariate and multivariate analyses.

The propensity score matching was used to balance the distributions of measured potentially confounding covariates for patients between groups. The logistic regression model included age at diagnosis, sex, surgical type, adjuvant therapy, histology, grade, and lymph node status was used to calculated the propensity scores. Thereafter, 1:2 pair matching without replacement was implemented by greedy nearest neighbor matching between each paired group, resulting in 3 matched sets (fissure vs T2a, fissure vs T2b, and fissure vs T3). The covariate balance effect was assessed by a standardized difference with a threshold of $0.10 .{ }^{12}$ A Cox proportional hazards model, which included age, sex, treatment, smoking status, histology, grade, lymph node status, and tumor side, was applied to assess the overall survival between 2 groups in each of the 3 matched sets. All statistical analyses were carried out using SAS 9.3 (SAS Institute, Inc, Cary, NC).

\section{RESULTS}

\section{Clinical Features}

A total of 1841 patients were retrospectively reviewed and demonstrated descriptive characteristics (Table 1). Preoperative workup for patients included 1706 cases of chest computed tomography (CT), 1338 cases of brain CT or magnetic resonance imaging, 1779 cases of B ultrasound or CT scan for abdomen, 923 cases of bone scan, and 637 cases positron emission tomography scan for distant metastases. Mediastinoscopy was routinely performed as part of preoperative workup in 1622 cases except those with early stage that was pathologically confirmed by transthoracic needle lung biopsy and mediastinal lymph node biopsy under the guidance of bronchoscope. Among these patients, 747 were pathologically staged as T2a; 445 as T2b; 596 as T3; and 53 cases were identified as the fissure group. The greatest dimension of tumor in the fissure group was $3.2 \pm 1.7 \mathrm{~cm}$. The missing of prediction of forced expiratory volume in 1 second for this study was 131 cases $(7.1 \%)$. We included and created a variable category of not gradable for the 127 cases $(6.9 \%)$ of missing data of cell grade. Because fissure invasion (which involves at least 2 lobes) was present (Video 1), the proportion of right side of disease and patients who underwent pneumonectomy or bilobectomy was higher than that of T2 disease. After propensity score matching, patients in each matched set were well balanced on all baseline characteristics (Table 2). 
TABLE 1. Demographic and pathologic data of 1841 patients

\begin{tabular}{|c|c|c|c|c|c|c|}
\hline & $\begin{array}{c}\text { T2a } \\
(N=747)\end{array}$ & $\begin{array}{c}\text { T2b } \\
(\mathrm{N}=\mathbf{4 4 5})\end{array}$ & $\begin{array}{c}\text { T3 } \\
(\mathrm{N}=\mathbf{5 9 6})\end{array}$ & $\begin{array}{c}\text { Fissure } \\
(\mathrm{N}=\mathbf{5 3})\end{array}$ & $\begin{array}{c}\text { Total } \\
(\mathbf{N}=\mathbf{1 8 4 1})\end{array}$ & $P$ value \\
\hline Age at diagnosis & & & & & & $<.0001$ \\
\hline $\mathrm{N}$ & 747 & 445 & 596 & 53 & 1841 & \\
\hline Mean (SD) & $68.9(10.4)$ & $67.9(10.9)$ & $66.3(10.6)$ & $67.0(8.7)$ & $67.7(10.6)$ & \\
\hline FEV $1 \%$ & & & & & & .2176 \\
\hline $\mathrm{N}$ & 692 & 408 & 565 & 45 & 1710 & \\
\hline Mean (SD) & $79.9(21.0)$ & $80.2(21.2)$ & 77.4 (18.7) & $77.1(18.2)$ & $79.2(20.3)$ & \\
\hline Sex & & & & & & .0022 \\
\hline Male & $377(50.5 \%)$ & $261(58.7 \%)$ & $357(59.9 \%)$ & $27(50.9 \%)$ & $1022(55.5 \%)$ & \\
\hline Female & $370(49.5 \%)$ & $184(41.3 \%)$ & $239(40.1 \%)$ & $26(49.1 \%)$ & $819(44.5 \%)$ & \\
\hline Surgical type & & & & & & $<.0001$ \\
\hline Pneumonectomy & $18(2.4 \%)$ & $38(8.5 \%)$ & $54(9.1 \%)$ & $13(24.5 \%)$ & $123(6.7 \%)$ & \\
\hline Bilobectomy & $21(2.8 \%)$ & $14(3.1 \%)$ & $31(5.2 \%)$ & $19(35.8 \%)$ & $85(4.6 \%)$ & \\
\hline Lobectomy* & $469(62.8 \%)$ & $287(64.5 \%)$ & $395(66.3 \%)$ & $14(26.4 \%)$ & $1165(63.3 \%)$ & \\
\hline Sublobe resection $\dagger$ & $239(32.0 \%)$ & $106(23.8 \%)$ & $116(19.5 \%)$ & $7(13.2 \%)$ & $468(25.4 \%)$ & \\
\hline Adjuvant therapy & & & & & & $<.0001$ \\
\hline No & $640(85.7 \%)$ & $358(80.4 \%)$ & $405(68.0 \%)$ & $42(79.2 \%)$ & $1445(78.5 \%)$ & \\
\hline Yes & $107(14.3 \%)$ & $87(19.6 \%)$ & $191(32.0 \%)$ & $11(20.8 \%)$ & $396(21.5 \%)$ & \\
\hline Smoking status & & & & & & .5392 \\
\hline Never & $142(19.0 \%)$ & $87(19.6 \%)$ & $100(16.8 \%)$ & $8(15.1 \%)$ & $337(18.3 \%)$ & \\
\hline Former & $398(53.3 \%)$ & $238(53.5 \%)$ & $305(51.2 \%)$ & $29(54.7 \%)$ & $970(52.7 \%)$ & \\
\hline Current & $207(27.7 \%)$ & $120(27.0 \%)$ & $191(32.0 \%)$ & $16(30.2 \%)$ & $534(29.0 \%)$ & \\
\hline Pack-y & & & & & & .1807 \\
\hline $\mathrm{N}$ & 595 & 350 & 485 & 44 & 1474 & \\
\hline Mean (SD) & $51.4(30.5)$ & $48.6(31.6)$ & $49.1(32.8)$ & $46.6(31.9)$ & 49.8 (31.6) & \\
\hline Histology & & & & & & $<.0001$ \\
\hline Adenocarcinoma & $486(65.1 \%)$ & $207(46.5 \%)$ & $275(46.1 \%)$ & $26(49.1 \%)$ & $994(54.0 \%)$ & \\
\hline Squamous & $180(24.1 \%)$ & $166(37.3 \%)$ & $212(35.6 \%)$ & $19(35.8 \%)$ & $577(31.3 \%)$ & \\
\hline Other NSCLC & $81(10.8 \%)$ & $72(16.2 \%)$ & $109(18.3 \%)$ & $8(15.1 \%)$ & $270(14.7 \%)$ & \\
\hline Grade & & & & & & $<.0001$ \\
\hline Well & $169(22.6 \%)$ & $79(17.8 \%)$ & $86(14.4 \%)$ & $12(22.6 \%)$ & $346(18.8 \%)$ & \\
\hline Moderate & $433(58.0 \%)$ & $219(49.2 \%)$ & $282(47.3 \%)$ & $24(45.3 \%)$ & $958(52.0 \%)$ & \\
\hline Poorly & $113(15.1 \%)$ & $115(25.8 \%)$ & $168(28.2 \%)$ & $14(26.4 \%)$ & $410(22.3 \%)$ & \\
\hline Not gradable & $32(4.3 \%)$ & $32(7.2 \%)$ & $60(10.1 \%)$ & $3(5.7 \%)$ & $127(6.9 \%)$ & \\
\hline Node & & & & & & $<.0001$ \\
\hline No & $633(84.7 \%)$ & $345(77.5 \%)$ & $422(70.8 \%)$ & $41(77.4 \%)$ & $1441(78.3 \%)$ & \\
\hline N1 & $114(15.3 \%)$ & $100(22.5 \%)$ & $174(29.2 \%)$ & $12(22.6 \%)$ & $400(21.7 \%)$ & \\
\hline Tumor side & & & & & & .4990 \\
\hline Left & $320(42.8 \%)$ & $186(42.2 \%)$ & $249(41.8 \%)$ & $17(32.1 \%)$ & $774(42.0 \%)$ & \\
\hline Right & $427(57.2 \%)$ & $257(57.8 \%)$ & $347(58.2 \%)$ & $36(67.9 \%)$ & $1067(58.0 \%)$ & \\
\hline
\end{tabular}

$S D$, Standard deviation; $F E V 1 \%$, forced expiratory volume in 1 second; $N S C L C$, non-small cell lung cancer. *Lobectomy for T2a, T2b, and T3, lobectomy + wedge resection or lobectomy + segmentectomy for fissure group. †Sublobe resection included wedge resection and segmentectomy.

\section{Survival Outcome}

The median follow-up time was 72.83 months (2-136 months) for 371 matched patients. From the 53 patients of fissure group, 50 were evaluable at 6 months, 42 were evaluable at 12 months, and 19 were evaluable at 60 months. From the other 418 patients, 307 were evaluable at 6 months, 262 were evaluable at 12 months, and 141 were evaluable at 60 months. The 5-year survival of the T2a, T2b, T3 and fissure groups were $64.2 \%$ (95\% confidence interval, 53.2-72.6), 54.6\% (95\% confidence interval, 44.7-65.8), 35.8\% (95\% confidence interval, 22.8-44.2) and $38.6 \%$ (95\% confidence interval, 25.0-52.2), respectively (Figure 1). By using univariate analyses, a similar survival was observed between the fissure group and T3 $(P=.93)$. The 5-year survival of the $\mathrm{T} 2 \mathrm{a}$ and $\mathrm{T} 2 \mathrm{~b}$ groups were significantly higher than that of the fissure group $(P=.01$ and $P=.02)$. Fissure invasion, age, sex, treatment, smoking status, histology, cell grade, lymph node status, 
TABLE 2. Demographic and pathologic data of 3 matched sets with their standardized difference

\begin{tabular}{|c|c|c|c|c|c|c|c|c|c|}
\hline & $\begin{array}{r}\text { Fissure } \\
(N=53)\end{array}$ & $\frac{\text { T2a }}{(N=106)}$ & $\begin{array}{l}\text { Standardized } \\
\text { difference }\end{array}$ & $\begin{array}{c}\text { Fissure } \\
(N=53)\end{array}$ & $\frac{\text { T2b }}{(N=106)}$ & $\begin{array}{l}\text { Standardized } \\
\text { difference }\end{array}$ & $\frac{\text { Fissure }}{(\mathrm{N}=\mathbf{5 3})}$ & $\frac{T 3}{(N=106)}$ & $\begin{array}{l}\text { Standardized } \\
\text { difference }\end{array}$ \\
\hline Age (Mean \pm SD), $y^{*}$ & $67.0 \pm 8.7$ & $68.0 \pm 8.8$ & -0.031 & $67.0 \pm 8.7$ & $66.8 \pm 9.1$ & 0.015 & $67.0 \pm 8.7$ & $67.3 \pm 8.8$ & -0.011 \\
\hline BMI & $27.3 \pm 4.7$ & $26.8 \pm 5.5$ & 0.023 & $27.3 \pm 4.7$ & $27.7 \pm 4.5$ & -0.013 & $27.3 \pm 4.7$ & $27.5 \pm 6.4$ & -0.002 \\
\hline FEV1\% & $77.1 \pm 18.2$ & $81.5 \pm 20.1$ & -0.070 & $77.1 \pm 18.2$ & $276.7 \pm 22.8$ & 0.007 & $77.1 \pm 18.2$ & $75.9 \pm 17.4$ & 0.033 \\
\hline Sex (Male), No. $(\%)^{*}$ & $27(50.9)$ & $63(59.4)$ & -0.071 & $27(50.9)$ & $66(62.3)$ & -0.088 & $27(50.9)$ & $63(59.4)$ & -0.068 \\
\hline \multicolumn{10}{|l|}{ Surgical type No. $(\%)^{*}$} \\
\hline Pneumonectomy & $13(24.5)$ & $23(21.7)$ & 0.002 & $13(24.5)$ & $27(25.5)$ & -0.001 & $13(24.5)$ & $29(27.4)$ & -0.002 \\
\hline Bilobectomy & $19(35.8)$ & $21(19.8)$ & 0.065 & $19(35.8)$ & $23(21.7)$ & 0.052 & $19(35.8)$ & $31(29.2)$ & 0.029 \\
\hline Lobectomy $\dagger$ & $14(26.4)$ & $47(44.3)$ & -0.070 & $14(26.4)$ & $42(39.6)$ & -0.030 & $14(26.4)$ & $32(30.2)$ & 0.058 \\
\hline Sublobe resection $\ddagger$ & $7(13.2)$ & $15(14.2)$ & -0.002 & $7(13.2)$ & $13(13.2)$ & 0 & $7(13.2)$ & $14(13.2)$ & 0 \\
\hline Adjuvant therapy, No. (\%) & $11(20.8)$ & $12(11.3)$ & 0.010 & $11(20.8)$ & $24(22.6)$ & -0.004 & $11(20.8)$ & $35(33.0)$ & -0.033 \\
\hline \multicolumn{10}{|l|}{ Smoking status, No. $(\%)^{*}$} \\
\hline Never & $8(15.1)$ & $19(17.9)$ & 0.013 & $8(15.1)$ & $16(15.1)$ & 0 & $8(15.1)$ & $20(18.9)$ & 0.016 \\
\hline Former & $29(54.7)$ & $59(55.7)$ & 0.009 & $29(54.7)$ & $56(52.8)$ & 0.002 & $29(54.7)$ & $58(54.7)$ & 0 \\
\hline Current & $16(30.2)$ & $28(26.4)$ & 0.323 & $16(30.2)$ & $34(32.1)$ & 0.002 & $16(30.2)$ & $28(26.4)$ & 0.023 \\
\hline Pack-y (mean \pm SD), y & $46.6 \pm 31.9$ & $51.0 \pm 28.0$ & 0.021 & $46.6 \pm 31.9$ & $49.5 \pm 35.1$ & -0.013 & $46.6 \pm 31.9$ & $50.1 \pm 32.6$ & -0.018 \\
\hline Tumor size (mean $\pm \mathrm{SD}$ ), $\mathrm{cm}$ & $3.2 \pm 1.7$ & $2.3 \pm 0.8$ & -0.002 & $2.2 \pm 0.6$ & $2.3 \pm 0.7$ & -0.001 & $2.2 \pm 0.6$ & $2.2 \pm 0.6$ & 0 \\
\hline \multicolumn{10}{|l|}{ Histology* } \\
\hline Adenocarcinoma & $26(49.1 \%)$ & $59(55.7 \%)$ & -0.008 & $26(49.1 \%)$ & $44(41.5 \%)$ & 0.021 & $26(49.1 \%)$ & $42(39.6 \%)$ & -0.055 \\
\hline Squamous & $19(35.8 \%)$ & $38(35.8 \%)$ & 0 & $19(35.8 \%)$ & $46(43.4 \%)$ & -0.024 & $19(35.8 \%)$ & $49(46.2 \%)$ & -0.032 \\
\hline Other NSCLC & $8(15.1 \%)$ & $9(8.5 \%)$ & 0.017 & $8(15.1 \%)$ & $16(15.1 \%)$ & 0 & $8(15.1 \%)$ & $15(14.2 \%)$ & 0.001 \\
\hline \multicolumn{10}{|l|}{ Grade* } \\
\hline Well & $12(22.6 \%)$ & $24(22.6 \%)$ & 0 & $12(22.6 \%)$ & $24(22.6 \%)$ & 0 & $12(22.6 \%)$ & $12(11.3 \%)$ & 0.076 \\
\hline Moderate & $24(45.3 \%)$ & $62(58.5 \%)$ & 0.079 & $24(45.3 \%)$ & $43(40.6 \%)$ & 0.033 & $24(45.3 \%)$ & $53(50.0 \%)$ & -0.034 \\
\hline Poorly & $14(26.4 \%)$ & $17(16.0 \%)$ & 0.060 & $14(26.4 \%)$ & $31(29.2 \%)$ & 0.039 & $14(26.4 \%)$ & $35(33.0 \%)$ & -0.045 \\
\hline Not gradable & $3(5.7 \%)$ & $3(2.8 \%)$ & 0.003 & $3(5.7 \%)$ & $8(7.5 \%)$ & 0.002 & $3(5.7 \%)$ & $6(5.7 \%)$ & 0 \\
\hline \multicolumn{10}{|l|}{ Node* } \\
\hline No & $41(77.4 \%)$ & $78(73.6 \%)$ & 0.013 & $41(77.4 \%)$ & $81(76.4 \%)$ & 0.001 & $41(77.4 \%)$ & $64(60.4 \%)$ & 0.082 \\
\hline N1 & $12(22.6 \%)$ & $28(26.4 \%)$ & -0.014 & $12(22.6 \%)$ & $25(23.6 \%)$ & -0.001 & $12(22.6 \%)$ & $42(39.6 \%)$ & -0.066 \\
\hline Tumor side, right & $36(67.9 \%)$ & $62(58.5 \%)$ & 0.019 & $36(67.9 \%)$ & $68(64.2 \%)$ & 0.008 & $36(67.9 \%)$ & $64(60.4 \%)$ & 0.012 \\
\hline
\end{tabular}

$S D$, Standard deviation; $B M I$, body mass index; $F E V I \%$, forced expiratory volume in 1 second; $N S C L C$, non-small cell lung cancer. *Variables used for matching. $\dagger$ Lobectomy for T2a, T2b, and T3, lobectomy + wedge resection or lobectomy + segmentectomy for fissure group. ‡̦Sublobe resection included wedge resection and segmentectomy.

and tumor side were included in the Cox proportional hazards model. Multivariate analyses indicate that the fissure group had a similar risk of dying as the T3 group (hazard ratio, 1.10; 95\% confidence interval, 0.69-1.37) and was at a significantly higher risk compared with the T2a group (hazard ratio, 2.34; 95\% confidence interval, 1.50-3.39) and $\mathrm{T} 2 \mathrm{~b}$ group (hazard ratio, $1.71 ; 95 \%$ confidence interval, 1.19-2.76) (Table 3 and Tables E1-E3).

\section{DISCUSSION}

The definition of the invasion of the adjacent lobe was not highlighted in proposals for the eighth edition of TNM classification because of its small proportion number and remains $\mathrm{T} 2$ as expressed in the Union for International Cancer Control TNM Supplement. In the eighth edition of the TNM classification, if tumors were greater than $3 \mathrm{~cm}$ and less than $5 \mathrm{~cm}$ tumor invading the fissures to the adjacent lobe could be defined as $\mathrm{T} 2 \mathrm{a}$ or $\mathrm{T} 2 \mathrm{~b}$, according to the greatest dimension of tumor. Although tumors of this type of disease are less than $5 \mathrm{~cm}$, they involve more lobe invasion and seem to have a poor survival, compared with T2 disease. To clarify what the $\mathrm{T}$ category for this type of lung cancer should be in the eighth edition of the TNM classification system, we compared survival outcomes between patients with such a fissure invasion and those staged as T2 and T3 diseases. The results supported a similar survival and risk of dying between the fissure group and $\mathrm{T} 3$ disease.

The survival of patients with NSCLC invading the fissure to the adjacent lobe has seldom been reported, and the results are controversial. Riquet and colleagues ${ }^{13}$ reported NSCLC with such a fissure invasion to an adjacent lobe was an independent factor of poor prognosis and visceral pleura invasion. Nonaka and colleagues ${ }^{14}$ found that the 5 -year survival of 28 patients with squamous cell 


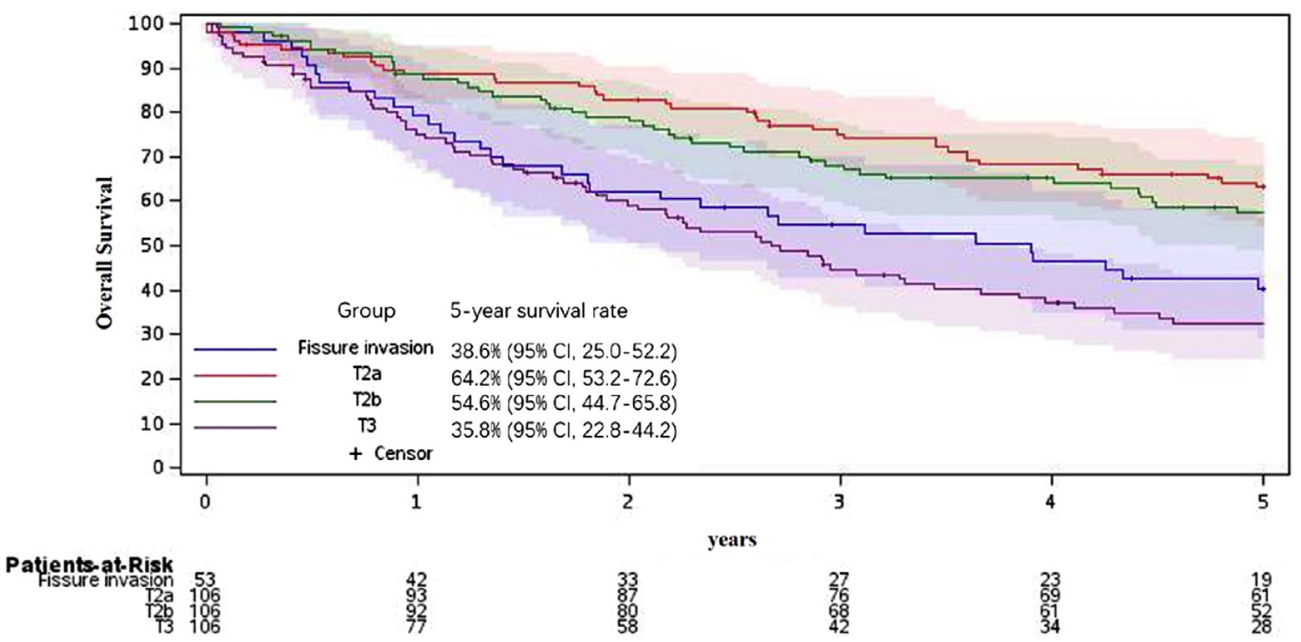

FIGURE 1. Overall survival of matched patients classified by the 8th edition TNM classification. Between fissure invasion and T2a, $P=.01$; between fissure invasion and T2b, $P=.02$; and between fissure invasion and T3, $P=.93$. $C I$, Confidence interval.

carcinomas in cases of adjacent lobe invasion was similar to that of T2 disease and thus concluded that tumors with adjacent lobe invasion should be classified as $\mathrm{T} 2$ in squamous cell carcinoma. Ohtaki and colleagues ${ }^{15}$ divided lung cancer with such a fissure invasion into the invasion across complete and incomplete fissure and found the complete fissure was associated with a better prognosis. They proposed lung cancer with invasion across the complete fissure should be classified as $\mathrm{T} 2 \mathrm{~b}$, but lung cancer with invasion across the incomplete fissure did not require an adjustment of the $\mathrm{T}$ category. However, Haam and colleagues ${ }^{16}$ reported that the overall survival and disease-free survival of patients with direct adjacent lobe invasion were similar to those of T3; the $\mathrm{T}$ category should be classified as $\mathrm{T} 3$ rather than $\mathrm{T} 2$. The discrepancies of $\mathrm{T}$ category may be due to the different inclusion criteria among studies in which node status and surgical type may have an effect on prognosis, suggesting further study is essential to clarify.

Lymph node involvement has been a common prognostic factor for NSCLC. Different lymph node status was included in previously reported studies in which the effect of lymph node involvement on survival was not excluded. ${ }^{5,6,14}$ Therefore, the conclusion of $\mathrm{T}$ category was still controversial. To evaluate the effect of $\mathrm{T}$ category on survival, only 2 studies, in which $\mathrm{T}$ category was classified by the seventh edition of TNM classification, excluded patients with lymph node involvement and concluded that NSCLC invading the fissure to the adjacent lobe should be classified as T3. ${ }^{15}$ Although cases with $\mathrm{N} 1$ involvement were included in our study because of small cases of this type of disease, the effect of different lymph node status on survival was maximally reduced by propensity scores matching. As with previously reported studies in which lymph node involvement was excluded, our results showed NSCLC invading the fissure to the adjacent lobe had a similar survival with T3 disease.

Pneumonectomy is a well-known risk prognostic factor for lung cancer, and controversy remains as to whether pneumonectomy is appropriate for NSCLC invading the fissure to the

TABLE 3. Summary of multivariate analyses for survival of $\mathbf{3}$ matched cohorts

\begin{tabular}{|c|c|c|c|c|c|}
\hline Variable & $\mathbf{N}$ & Events & Median survival time (y) & HR $(95 \%$ CI) & $P$ value \\
\hline & & & & & .8611 \\
\hline $\mathrm{T} 3$ & 106 & $80(75 \%)$ & 2.8 & - & \\
\hline \multirow[t]{2}{*}{ Fissure } & 53 & $41(77 \%)$ & 3.6 & $1.10(0.69-1.37)$ & \\
\hline & & & & & .0046 \\
\hline $\mathrm{T} 2 \mathrm{~b}$ & 106 & $69(65 \%)$ & 6.1 & - & \\
\hline \multirow[t]{2}{*}{ Fissure } & 53 & $41(77 \%)$ & 3.6 & $1.71(1.19-2.76)$ & \\
\hline & & & & & .0004 \\
\hline $\mathrm{T} 2 \mathrm{a}$ & 106 & $76(72 \%)$ & 6.7 & - & \\
\hline Fissure & 53 & $41(77 \%)$ & 3.6 & $2.34(1.50-3.39)$ & \\
\hline
\end{tabular}

$H R$, Hazard ratio; $C I$, confidence interval. 


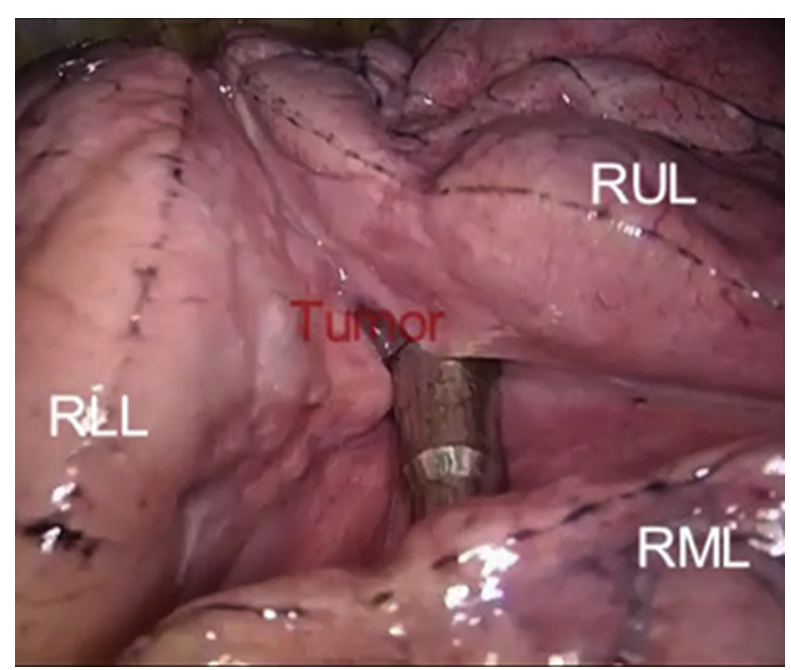

VIDEO 1. The tumor invaded the fissure to the adjacent lobe and was removed by combined segmentectomy (dorsal segment of lower lobe and posterior segment of upper lobe). $R U L$, right upper lobe; $R L L$, right lower lobe; $R M L$, right middle lobe. Video available at: http://www.jtcvsonline. org/article/S0022-5223(17)31723-3/fulltext.

adjacent lobe. Demir and colleagues ${ }^{7}$ reported the survival of patients with this type of disease who underwent pneumonectomy was worse than in those who did not receive pneumonectomy. However, Yang and colleagues ${ }^{4}$ found a better survival in patients who underwent pneumonectomy, compared with those receiving lesser resections. Because the feature of fissure invasion (which involves at least 2 lobes) was involved, the proportion of patients who underwent pneumonectomy or bilobectomy was higher than that of T2 disease. The effect of surgical type on prognosis also was considered and reduced by propensity scores matching in our study. After matching, the proportion of pneumonectomy and bilobectomy was comparable between groups in matched sets. The proportion of pneumonectomy was 13 $(24.5 \%)$ versus $23(21.7 \%)$ between fissure invasion and T2a, $13(24.5 \%)$ versus $27(25.5 \%)$ between fissure invasion and $\mathrm{T} 2 \mathrm{~b}$, and $13(24.5 \%)$ versus $29(27.4 \%)$ between fissure invasion and T3. In addition, the ratio of right or left pneumonectomy was similar, with the ratio of right pneumonectomy slightly higher than that of left pneumonectomy. The effect of surgical type on result was minimized; the case-matched study made our $\mathrm{T}$ category results more reliable than previous studies.

\section{Study Limitations}

This study had certain limitations. The number of cases was relatively small and included patients with lymph node involvement. NSCLC with an adjacent lobe invasion is rare; even in other studies in which patients with $\mathrm{N} 1$ or $\mathrm{N} 2$ were included, only 18 to 90 patients had an adjacent lobe invasion. Missing data of lung function and functional status made it difficult to balance the higher likelihood of choosing patients to receive sublobe resection. Also, few details were available about the different surgeon levels and surgical techniques that may affect the decision of surgical procedure. However, the balance of surgical type after matching can alleviate the impact of these concerns. The population in this study was still heterogeneous, because we cannot be certain that the propensity score perfectly neutralized all of the confounding variables, such as gene mutations and targeted agents. Although this study has a high level of evidence, the conclusions will never be as strong as those from prospective multicenter randomized control trials. Further validation studies of recent large patient sample sizes from multiple institutions will enable gene mutation status and target agents to be considered.

\section{CONCLUSIONS}

On the basis of our single-institution study, we propose that classification of the invasion of the adjacent lobe should be further investigated and the impact on patients' prognoses validated as a T3 disease in the eighth edition of TNM classification.

\section{Conflict of Interest Statement}

Authors have nothing to disclose with regard to commercial support.

The authors thank Pamela J. Neville and Marlene M. Boyd, for their professional editing and technical assistance with the article.

\section{References}

1. Goldstraw P, Crowley J, Chansky K, Giroux DJ, Groome PA, Rami-Porta R, et al. The IASLC Lung Cancer Staging Project: proposals for the revision of the TNM stage groupings in the forthcoming (seventh) edition of the TNM Classification of malignant tumours. J Thorac Oncol. 2007;2:706-14.

2. Rami-Porta R, Ball D, Crowley J, Giroux DJ, Jett J, Travis WD, et al. The IASLC Lung Cancer Staging Project: proposals for the revision of the T descriptors in the forthcoming (seventh) edition of the TNM classification for lung cancer. J Thorac Oncol. 2007;2:593-602.

3. Wittekind C. TNM Supplement: A Commentary on Uniform Use. 4th ed. New York, NY: Wiley-Blackwell; 2012.

4. Yang HX, Hou X, Lin P, Yang H, Zeng CG, Rong TH, et al. Peripheral direct adjacent lobe invasion non-small cell lung cancer has a similar survival to that of parietal pleural invasion T3 disease. J Thorac Oncol. 2009;4:1342-6.

5. Okada M, Tsubota N, Yoshimura M, Miyamoto Y, Matsuoka H. How should interlobar pleural invasion be classified? Prognosis of resected T3 non-small cell lung cancer. Ann Thorac Surg. 1999;68:2049-52.

6. Miura H, Taira O, Uchida O, Kato H. Invasion beyond interlobar pleura in nonsmall cell lung cancer. Chest. 1998;114:1301-4.

7. Demir A, Gunluoglu MZ, Sansar D, Melek H, Dincer SI. Staging and resection of lung cancer with minimal invasion of the adjacent lobe. Eur J Cardiothorac Surg. 2007;32:855-8.

8. Goldstraw P, Chansky K, Crowley J, Rami-Porta R, Asamura H, Eberhardt WE, et al. The IASLC Lung Cancer Staging Project: proposals for revision of the TNM stage groupings in the forthcoming (Eighth) Edition of the TNM Classification for Lung Cancer. J Thorac Oncol. 2016;11:39-51.

9. Yang P, Allen MS, Aubry MC, Wampfler JA, Marks RS, Edell ES, et al. Clinical features of 5,628 primary lung cancer patients: experience at Mayo Clinic from 1997 to 2003. Chest. 2005;128:452-62.

10. Sun Z, Aubry MC, Deschamps C, Marks RS, Okuno SH, Williams BA, et al. Histologic grade is an independent prognostic factor for survival in non-small cell lung cancer: an analysis of 5018 hospital- and 712 population-based cases. $J$ Thorac Cardiovasc Surg. 2006;131:1014-20. 
11. Rami-Porta R, Bolejack V, Crowley J, Ball D, Kim J, Lyons G, et al. The IASLC Lung Cancer Staging Project: proposals for the revisions of the T descriptors in the forthcoming Eighth Edition of the TNM Classification for Lung Cancer. $J$ Thorac Oncol. 2015;10:990-1003.

12. McMurry TL, Hu Y, Blackstone EH, Kozower BD. Propensity scores: methods, considerations, and applications in the Journal of Thoracic and Cardiovascular Surgery. J Thorac Cardiovasc Surg. 2015;150:14-9.

13. Riquet M, Berna P, Arame A, Mordant P, Das Neves Pereira JC, Foucault C, et al. Lung cancer invading the fissure to the adjacent lobe: more a question of spreading mode than a staging problem. Eur J Cardiothorac Surg. 2012;41:1047-51.

14. Nonaka M, Kataoka D, Yamamoto S, Horichi N, Ohgiya Y, Kushima M, et al. Outcome following surgery for primary lung cancer with interlobar pleural invasion. Surg Today. 2005;35:22-7.
15. Ohtaki Y, Hishida T, Yoshida J, Ishii G, Kawase A, Aokage K, et al The clinical outcome of non-small cell lung cancer patients with adjacent lobe invasion: the optimal classification according to the status of the in terlobar pleura at the invasion point. Eur J Cardiothorac Surg. 2013;43: 302-9.

16. Haam SJ, Park IK, Paik HC, Ishii G, Kawase A, Aokage K, et al. T-stage of nonsmall cell lung cancer directly invading an adjacent lobe. Eur J Cardiothorac Surg. 2012;42:807-11.

Key Words: adjacent lobe invasion, non-small cell lung cancer, TNM staging 
TABLE E1. Multivariate analyses for survival of matched cohort (fissure group vs T2a)

\begin{tabular}{|c|c|c|c|c|c|c|c|c|}
\hline \multicolumn{9}{|c|}{ Survival summary } \\
\hline Variable & $\mathbf{N}$ & Events & $\begin{array}{c}\text { Median } \\
\text { years }\end{array}$ & $\begin{array}{l}\text { 5-y survival \% } \\
(95 \% \text { CI })\end{array}$ & $\begin{array}{l}\text { Cox univariate } \\
\text { HR }(95 \% \text { CI })\end{array}$ & $\begin{array}{c}\text { Cox univariate } \\
\text { score } P \text { value }\end{array}$ & $\begin{array}{l}\text { Cox multivariate } \\
\text { HR }(95 \% \text { CI })\end{array}$ & $\begin{array}{c}\text { Cox multivariate } \\
\text { likelihood ratio } \\
P \text { value }(n=159)\end{array}$ \\
\hline Group & & & & & & .0015 & & .0004 \\
\hline $\mathrm{T} 2 \mathrm{a}$ & 106 & $76(72 \%)$ & 6.7 & $64.2(53.2-72.6)$ & - & & - & \\
\hline Fissure & 53 & $41(77 \%)$ & 3.6 & $38.6(25.0-52.2)$ & $1.89(1.22-2.65)$ & & $2.34(1.50-3.39)$ & \\
\hline Sex & & & & & & .0005 & & .0003 \\
\hline Male & 90 & $77(86 \%)$ & 4.7 & $46.9(36.5-57.3)$ & - & & - & \\
\hline Female & 69 & $39(57 \%)$ & 7.7 & $66.0(54.4-77.6)$ & $0.51(0.35-0.75)$ & & $0.45(0.28-0.70)$ & \\
\hline Treatment & & & & & & .5135 & & .7388 \\
\hline Surgery only & 136 & $102(75 \%)$ & 5.2 & $54.4(45.8-62.9)$ & - & & - & \\
\hline Surgery adjuvant chemo & 23 & $14(61 \%)$ & 5.7 & $58.7(38.0-79.5)$ & $0.83(0.47-1.45)$ & & $0.90(0.47-1.70)$ & \\
\hline Cigarette smoking status & & & & & & .6405 & & .2481 \\
\hline Never & 27 & $18(67 \%)$ & 5.8 & $59.9(40.6-79.2)$ & - & & - & \\
\hline Former & 88 & $64(73 \%)$ & 5.7 & $56.7(46.1-67.3)$ & $1.09(0.64-1.83)$ & & $0.91(0.50-1.65)$ & \\
\hline Current/ever & 44 & $34(77 \%)$ & 5.0 & $48.8(33.8-63.8)$ & $1.28(0.72-2.27)$ & & $1.34(0.68-2.64)$ & \\
\hline Histology & & & & & & .4846 & & .1143 \\
\hline Adenocarcinoma & 85 & $62(73 \%)$ & 6.0 & $57.0(46.2-67.8)$ & - & & - & \\
\hline Squamous & 57 & $41(72 \%)$ & 5.4 & $58.2(45.1-71.3)$ & $1.06(0.72-1.58)$ & & $0.74(0.47-1.14)$ & \\
\hline Other NSCLC & 17 & $13(76 \%)$ & 3.0 & $35.3(12.6-58.0)$ & $1.45(0.79-2.64)$ & & $1.70(0.76-3.83)$ & \\
\hline Grade & & & & & & .3001 & & .9524 \\
\hline Well & 36 & $24(67 \%)$ & 7.1 & $65.1(49.1-81.1)$ & - & & - & \\
\hline Moderate & 86 & $66(77 \%)$ & 5.2 & $54.0(43.2-64.9)$ & $1.46(0.91-2.34)$ & & $1.07(0.63-1.83)$ & \\
\hline Poorly & 31 & $21(68 \%)$ & 5.1 & $50.0(32.1-67.9)$ & $1.23(0.68-2.21)$ & & $0.93(0.48-1.83)$ & \\
\hline Nongradable & 6 & $5(83 \%)$ & 3.9 & $33.3(0.0-71.1)$ & $2.07(0.79-5.46)$ & & $1.14(0.32-4.06)$ & \\
\hline Node & & & & & & .5136 & & .5397 \\
\hline No & 119 & $87(73 \%)$ & 5.7 & $56.5(47.4-65.7)$ & - & & - & \\
\hline N1 & 40 & $29(73 \%)$ & 5.1 & $50.9(35.1-66.7)$ & $1.15(0.76-1.75)$ & & $1.17(0.71-1.95)$ & \\
\hline Side & & & & & & .9085 & & .6082 \\
\hline Left & 61 & $45(74 \%)$ & 5.6 & $59.1(46.5-71.8)$ & - & & - & \\
\hline Right & 98 & $71(72 \%)$ & 5.2 & $52.5(42.4-62.6)$ & $1.02(0.70-1.49)$ & & $0.90(0.60-1.34)$ & \\
\hline Age at diagnosis & 159 & $116(73 \%)$ & 5.4 & $55.0(47.1-62.9)$ & $1.028(1.005-1.051)$ & .0148 & $1.030(1.006-1.056)$ & .0149 \\
\hline
\end{tabular}

$C I$, Confidence interval; $H R$, hazard ratio; $N S C L C$, non-small cell lung cancer. 
TABLE E2. Multivariate analyses for survival of matched cohort (fissure group vs T2b)

\begin{tabular}{|c|c|c|c|c|c|c|c|c|}
\hline \multicolumn{9}{|c|}{ Survival summary } \\
\hline Variable & $\mathbf{N}$ & Events & $\begin{array}{c}\text { Median } \\
\text { Years }\end{array}$ & $\begin{array}{c}\text { 5-y survival } \\
(95 \% \mathrm{CI})\end{array}$ & $\begin{array}{l}\text { Cox univariate } \\
\text { HR }(95 \% \text { CI })\end{array}$ & $\begin{array}{c}\text { Cox } \\
\text { univariate } \\
\text { score } P \text { value }\end{array}$ & $\begin{array}{c}\text { Cox multivariate } \\
\text { HR }(95 \% \text { CI })\end{array}$ & $\begin{array}{c}\text { Cox multivariate } \\
\text { likelihood ratio } \\
P \text { value }(n=159)\end{array}$ \\
\hline Group & & & & & & .0188 & & .0046 \\
\hline $\mathrm{T} 2 \mathrm{~b}$ & 106 & $69(65 \%)$ & 6.1 & $54.6(44.7-65.8)$ & - & & - & \\
\hline Fissure & 53 & $41(77 \%)$ & 3.6 & $38.6(25.0-52.2)$ & $1.59(1.10-2.39)$ & & $1.71(1.19-2.76)$ & \\
\hline Sex & & & & & & .0228 & & .0021 \\
\hline Male & 93 & $71(76 \%)$ & 4.4 & $45.1(34.5-55.6)$ & - & & - & \\
\hline Female & 66 & $39(59 \%)$ & 7.1 & $56.9(44.5-69.3)$ & $0.64(0.43-0.94)$ & & $0.50(0.32-0.79)$ & \\
\hline Treatment & & & & & & .5061 & & .5962 \\
\hline Surgery only & 124 & $88(71 \%)$ & 4.9 & $49.0(39.9-58.1)$ & - & & - & \\
\hline Surgery adjuvant chemo & 35 & $22(63 \%)$ & 5.7 & $54.1(36.7-71.4)$ & $0.85(0.53-1.36)$ & & $1.16(0.68-1.97)$ & \\
\hline Cigarette smoking status & & & & & & .6076 & & .1024 \\
\hline Never & 24 & $14(58 \%)$ & 5.1 & $54.7(33.8-75.6)$ & - & & - & \\
\hline Former & 85 & $60(71 \%)$ & 5.1 & $51.0(40.1-61.9)$ & $1.10(0.61-1.97)$ & & $0.69(0.36-1.35)$ & \\
\hline Current/ever & 50 & $36(72 \%)$ & 4.3 & $46.1(31.5-60.8)$ & $1.31(0.70-2.43)$ & & $1.14(0.57-2.30)$ & \\
\hline Histology & & & & & & .5199 & & .0103 \\
\hline Adenocarcinoma & 70 & $48(69 \%)$ & 4.5 & $45.3(33.1-57.5)$ & - & & - & \\
\hline Squamous & 65 & $45(69 \%)$ & 5.8 & $59.5(47.2-71.9)$ & $0.90(0.59-1.36)$ & & $0.64(0.40-1.02)$ & \\
\hline Other NSCLC & 24 & $17(71 \%)$ & 1.7 & $39.1(19.2-59.1)$ & $1.25(0.72-2.18)$ & & $2.06(0.98-4.33)$ & \\
\hline Grade & & & & & & .4669 & & .4315 \\
\hline Well & 36 & $22(61 \%)$ & 5.7 & $55.5(38.6-72.4)$ & - & & - & \\
\hline Moderate & 67 & $52(78 \%)$ & 4.5 & $47.6(35.0-60.2)$ & $1.40(0.85-2.32)$ & & $1.38(0.77-2.49)$ & \\
\hline Poorly & 45 & $30(67 \%)$ & 2.8 & $46.7(31.8-61.7)$ & $1.12(0.64-1.96)$ & & $0.99(0.51-1.94)$ & \\
\hline Nongradable & 11 & $6(55 \%)$ & 8.4 & $58.3(26.8-89.9)$ & $0.94(0.38-2.31)$ & & $0.64(0.21-1.99)$ & \\
\hline Node & & & & & & .7922 & & .7721 \\
\hline No & 122 & $87(71 \%)$ & 4.9 & $48.4(39.2-57.6)$ & - & & - & \\
\hline N1 & 37 & $23(62 \%)$ & 5.4 & $56.3(39.6-73.1)$ & $0.94(0.59-1.49)$ & & $0.93(0.55-1.56)$ & \\
\hline Side & & & & & & .2450 & & .3623 \\
\hline Left & 55 & $39(71 \%)$ & 4.5 & $48.8(34.8-62.8)$ & - & & - & \\
\hline Right & 104 & $71(68 \%)$ & 5.1 & $50.8(40.9-60.7)$ & $0.79(0.54-1.17)$ & & $0.82(0.54-1.25)$ & \\
\hline Age at diagnosis & 159 & $110(69 \%)$ & 5.1 & $50.1(42.0-58.2)$ & $1.012(0.990-1.034)$ & .2997 & $1.0246(0.9990-1.0509)$ & .0601 \\
\hline
\end{tabular}

$C I$, Confidence interval; $H R$, hazard ratio; $N S C L C$, non-small cell lung cancer. 
TABLE E3. Multivariate analyses for survival of matched cohort (fissure group vs T3)

\begin{tabular}{|c|c|c|c|c|c|c|c|c|}
\hline \multicolumn{9}{|c|}{ Survival summary } \\
\hline Variable & $\mathbf{N}$ & Events & $\begin{array}{c}\text { Median } \\
\text { years }\end{array}$ & $\begin{array}{c}\text { 5-y survival } \\
(95 \% \mathrm{CI})\end{array}$ & $\begin{array}{l}\text { Cox univariate } \\
\text { HR }(95 \% \text { CI })\end{array}$ & $\begin{array}{c}\text { Cox } \\
\text { univariate } \\
\text { score } \boldsymbol{P} \text { value }\end{array}$ & $\begin{array}{l}\text { Cox multivariate } \\
\text { HR }(95 \% \text { CI })\end{array}$ & $\begin{array}{c}\text { Cox multivariate } \\
\text { likelihood ratio } \\
P \text { value }(n=158)\end{array}$ \\
\hline Group & & & & & & .9267 & & .8611 \\
\hline $\mathrm{T} 3$ & 106 & $81(76 \%)$ & 2.8 & $35.8(22.8-44.2)$ & - & & - & \\
\hline Fissure & 53 & $41(77 \%)$ & 3.6 & $38.6(25.0-52.2)$ & $0.98(0.67-1.43)$ & & $1.10(0.69-1.37)$ & \\
\hline Sex & & & & & & .0107 & & .1426 \\
\hline Male & 90 & $75(83 \%)$ & 2.3 & $27.5(17.7-37.3)$ & - & & - & \\
\hline Female & 69 & $47(68 \%)$ & 3.4 & $43.3(31.2-55.5)$ & $0.62(0.43-0.90)$ & & $0.73(0.47-1.12)$ & \\
\hline Treatment & & & & & & .7734 & & .8562 \\
\hline Surgery only & 113 & $89(79 \%)$ & 2.9 & $34.0(24.8-43.2)$ & - & & - & \\
\hline Surgery adjuvant chemo & 46 & $33(72 \%)$ & 2.3 & $36.2(21.8-50.6)$ & $0.94(0.63-1.41)$ & & $0.96(0.61-1.50)$ & \\
\hline Cigarette smoking status & & & & & & .2470 & & .1998 \\
\hline Never & 28 & $23(82 \%)$ & 2.7 & $35.5(17.1-54.0)$ & - & & - & \\
\hline Former & 87 & $64(74 \%)$ & 3.3 & $40.1(29.3-50.9)$ & $0.87(0.54-1.40)$ & & $0.70(0.42-1.16)$ & \\
\hline Current/ever & 44 & $35(80 \%)$ & 2.0 & $22.0(9.0-35.0)$ & $1.24(0.73-2.10)$ & & $0.97(0.52-1.81)$ & \\
\hline Histology & & & & & & .0835 & & .8460 \\
\hline Adenocarcinoma & 68 & $52(76 \%)$ & 3.4 & $32.3(20.5-44.0)$ & - & & - & \\
\hline Squamous & 68 & $56(82 \%)$ & 1.8 & $32.4(20.6-44.1)$ & $1.30(0.89-1.91)$ & & $0.90(0.58-1.41)$ & \\
\hline Other NSCLC & 23 & $14(61 \%)$ & 2.8 & $45.8(24.9-66.6)$ & $0.70(0.38-1.26)$ & & $1.11(0.54-2.28)$ & \\
\hline Grade & & & & & & .0023 & & .0057 \\
\hline Well & 24 & $16(67 \%)$ & 3.9 & $44.0(23.7-64.3)$ & - & & - & \\
\hline Moderate & 77 & $65(84 \%)$ & 3.1 & $29.3(18.4-40.2)$ & $1.760(1.013-3.057)$ & & $1.78(0.94-3.38)$ & \\
\hline Poorly & 49 & $38(78 \%)$ & 1.8 & $26.7(13.6-39.7)$ & $1.97(1.10-3.54)$ & & $2.22(1.11-4.47)$ & \\
\hline Nongradable & 9 & $3(33 \%)$ & & $88.9(68.4-100.0)$ & $0.35(0.10-1.19)$ & & $0.43(0.11-1.65)$ & \\
\hline Node & & & & & & .1584 & & .1779 \\
\hline No & 105 & $82(78 \%)$ & 3.4 & $38.2(28.6-47.8)$ & - & & - & \\
\hline N1 & 54 & $40(74 \%)$ & 2.0 & $26.9(14.1-39.6)$ & $1.31(0.90-1.92)$ & & $1.34(0.88-2.03)$ & \\
\hline Side & & & & & & .6161 & & .4039 \\
\hline Left & 58 & $44(76 \%)$ & 2.6 & $37.5(24.4-50.6)$ & - & & - & \\
\hline Right & 100 & $78(78 \%)$ & 2.9 & $32.3(22.7-41.9)$ & $1.10(0.76-1.60)$ & & $1.19(0.79-1.78)$ & \\
\hline Age at diagnosis & 159 & $122(77 \%)$ & 2.8 & $34.4(26.7-42.2)$ & $1.0192(0.9994-1.0394)$ & .0574 & $1.025(1.002-1.049)$ & .0339 \\
\hline
\end{tabular}

$C I$, Confidence interval; $H R$, hazard ratio; $N S C L C$, non-small cell lung cancer. 